\title{
Addressing Health Costs and a Business Opportunity for Self-help Groups for Poor
}

\author{
S. K. Manivannan ${ }^{1 *}$ and M. Valliammal ${ }^{2}$ \\ 'Faculty of Management, SRM University, Vadapalani, Chennai - 600026, Tamil Nadu, India; \\ manivannan.srmmba@gmail.com \\ ${ }^{2}$ R and D Center, Bharathiar University, SRM B-School, Coimbatore - 641046, Tamil Nadu, India; valliammalm@gmail.com
}

\begin{abstract}
Objective: This research is focused on community pharmacy as a business proposal for the Self Help Groups, which help them not only as a business, but also reduce their own families and communities' dependence on commercially operated pharmacies for the majority of health needs. The key factors that can be used by policy makers to select the groups who can run the business are explored in the study. Methods: A descriptive empirical research method was followed and analysis of data carried out using SPSS statistical package. Findings: The findings include that the group members' demographic factors contribute much to their opting for community pharmacy. Improvements: The suggestions include the characteristics of the group members to be focused on by government agencies and the practical steps to start and grow the business through.
\end{abstract}

Keywords: Community Pharmacy, Jan Aushadhi, Self-help Groups

\section{Introduction}

In the famous Nobel lecture 'The Economics of Poverty', the author argues that the poor tend to pay more for the equivalent purchase for the same goods and services bought by their more affluent neighbor. But there is one other type of cost that is the most insidious compared to all the other costs faced by the poor namely the health related expenses.

In previous study 2 , the findings reveal that the health related costs constitute about $73 \%$ of the affected person's median income. Of the costs, which include both direct and indirect costs (such as loss of daily income), cost of medicines constitute about $50 \%$ of the expenses, higher than even hospitalization. When you take in to account the recent remedial actions by the government such as health insurance, the obvious gap is that of the cost of medicines which needs significant financial outgo for the poor. Recognizing this the Tamil Nadu government is also thinking of promoting government aided discount medical shops and the Central government initiated the 'Jan Aushadhi' to provide medicines at discounted prices.

Still the scope for intervention is a lot more as much more needs to be done for reaching the needy at the time of their want. For example the extent of availability for the poor can be improved at the time and place of their choice. While the affluent can afford 24 hour pharmacies like Apollo Pharmacy ${ }^{3}$, the overhead involved in maintaining such extended services to poor might be too costly. Added to this is the scale of purchases by poor also might be a concern for the fair price outlets forcing them to incur extra costs for the small quantities purchased by the poor.

This article will focus on how SHGs can adopt pharmacy business and provide inputs to the government to focus their efforts in securing the support of existing SHGs to spread the community pharmacy as a business proposition and as a service. Such an initiative will provide a self-help oriented solution for the health costs of poor and how it can be operationalized.

*Author for correspondence 


\section{Research Objective}

Objective of this paper is to explore the readiness with which the SHG members are likely to adopt the business idea of pharmacy as a community service and business proposition and the factors that help in this regard. Since this business is a practical solution for providing medicines to the poor at an affordable cost of operations and still meeting most of the requirements of poor in meeting their health needs, government policy makers should use the findings of this study to encourage SHGs to take it up.

\section{Literature Survey}

$\operatorname{In}^{4}$ opine that the policy makers must focus on how to improve provision of medicines to the population, regulate drug prices and put in place evidence based drug approval. Further the government had banned over 300 fixed dose drug combinations that had been very popular ${ }^{5}$. Further the poor also are burdened with excess cost for all their purchases as evidenced by ${ }^{6}$.

$\operatorname{In}^{z}$ expounds on the need for extending the business models of Microenterprises of Self-help Groups (SHGs) to businesses that also reduce the economic exclusion experienced by them, for example the increasingly costly health costs $^{\underline{8}}$ give a clear insight in to the buying behaviors of poor for health care.

The pharmaceutical industry in India is estimated to be at about Rs. 80,000 crore and the distribution is largely confined to unorganized sector. However the margins in the network can work up to a minimum of $40 \%$ and above $\frac{9-11}{}$.

The factors that determine SHG members to choose their business activity had been extensively discussed by and others $\frac{12-14}{}$. These factors were then used to frame the research hypotheses and the research instrument to be used.

The review of literature reveals that there had been no research on the business proposition of SHGs running a pharmacy business or how it can be operationalized.

\section{Methodology}

This study is exploring the idea of how a SHG can run a pharmacy as a business proposition. Since this line of activity by SHGs has not been explored before or any research done in this area, the study is proposed as a con- ceptual idea and validation of the idea using field survey of the SHG members on their reception and likely benefits from such an initiative. The conceptualization of this business used data from similar businesses conducted by SHGs so far and also how the pharmacy business itself is usually run, besides exploring government programs in this area.

The descriptive study used a structured questionnaire which had been field tested and had interviewed about 250 members of SHGs in urban and rural areas in Tamil $\mathrm{Nadu}$. The data was analyzed using statistical tools like ANOVA to test the research hypotheses.

\section{Research Hypotheses}

The following hypotheses were formulated based on the previous research on SHG policies of government, business choices etc. and are as follows.

H1: The propensity of SHG members to choose a new business like community pharmacy might vary based on whether they are living in Urban or Rural area.

$\mathrm{H} 2$ : The gender of the SHG members will impact the decision of the SHG to opt for pharmacy as their business.

H3: The average education level of the SHG members will impact the decision of the SHG to opt for pharmacy as their business.

\section{Discussion of Findings}

Based on the results of the ANOVA analysis in Table 1, the hypotheses that place of residence, level of education and gender will have significant impact on the decision by the SHG to go for pharmacy service is borne out by the data.

As can be seen from the mean values, urban groups are more likely to opt for opening a pharmacy as a business proposition compared to semi-urban and rural in that order of preference. Hence governmental agencies can initially focus on the urban SHGs for promoting the idea of community pharmacies to be run by SHGs.

Further women only SHGs are more likely to adopt pharmacy business than men only or mixed groups. This finding probably is surprising since women are usually seen to take up more traditional businesses like preparation of food articles, preserves and similar less risky businesses. However as we see in this study, women probably feel more inclined to take up this line of business 
since they are the ones who are emotionally attached to the health of their family and the health related benefits of this business drives them more than that of their counterparts.

The other finding relating to education level also shows considerable difference and as can be probably guessed, the more educated the SHG members are, the more likely that they adopt pharmacy as a business idea. Thus the governmental agencies can focus on the SHGs with educated members to show case the success of community pharmacies run by them so that other SHGs also might come forward to run such pharmacies later on.

Table 1. Results of ANOVA analysis for different profiled Self-help Groups

\begin{tabular}{|c|c|c|c|c|c|}
\hline \multirow{2}{*}{\multicolumn{2}{|c|}{$\begin{array}{l}\text { Profile of SHG members } \\
\text { Mean }\end{array}$}} & \multicolumn{2}{|c|}{ Values of } & \multirow[t]{2}{*}{ F-Value } & \multirow[t]{2}{*}{ P Value } \\
\hline & & \multicolumn{2}{|l|}{ SD } & & \\
\hline \multirow{3}{*}{$\begin{array}{l}\text { Place of } \\
\text { residence }\end{array}$} & Urban & 45.28 & 6.88 & \multirow[t]{3}{*}{12.067} & \multirow{3}{*}{$\begin{array}{l}0.000 \\
* * *\end{array}$} \\
\hline & $\begin{array}{l}\text { Semi- } \\
\text { Urban }\end{array}$ & 41.40 & 5.52 & & \\
\hline & Rural & 40.61 & 8.90 & & \\
\hline \multirow{3}{*}{$\begin{array}{l}\text { Gender } \\
\text { composition }\end{array}$} & Male only & 41.78 & 5.33 & \multirow[t]{3}{*}{8.166} & \multirow{3}{*}{$\begin{array}{l}0.00 \\
*\end{array}$} \\
\hline & $\begin{array}{l}\text { Female } \\
\text { only }\end{array}$ & 44.97 & 5.92 & & \\
\hline & Mixed & 42.73 & 6.88 & & \\
\hline \multirow{3}{*}{$\begin{array}{l}\text { Average } \\
\text { Education } \\
\text { level }\end{array}$} & $\begin{array}{l}\text { More than } \\
\text { school }\end{array}$ & 55.16 & 6.84 & \multirow[t]{3}{*}{10.559} & \multirow[t]{3}{*}{$\begin{array}{l}0.000 \\
* * *\end{array}$} \\
\hline & $\begin{array}{l}\text { Primary- } \\
\text { SSLC }\end{array}$ & 50.78 & 6.61 & & \\
\hline & $\begin{array}{l}\text { Minimum } \\
\text { literacy }\end{array}$ & 51.68 & 9.36 & & \\
\hline
\end{tabular}

Source: Research Data

\section{Conclusion and Suggestions}

To begin with the business proposition of community pharmacy to be run by the SHGs could be thought of in two stages.

The first stage of the pharmacy operations would be in the nature of catering to the drug needs of the group member families and if the group finances were good enough, the operations could also cater to the immediate neighborhood as the group matures in its ability to assess the business needs such as demand estimation, procurement and inventory control. In this initial stage the group must focus more on the Over the Counter (OTC) type of drugs that are likely to be consumed within the group and avoid self-medication within the members. The medicines can be procured in bulk with the aim for quality generics and demand good discounts on that account. Most OTC drugs also would not need expensive storage either, reducing the initial outlay. Such a strategy will aid in lower initial outlay for the business and an assured offtake of the goods and a better inventory management.

As the SHGs gain traction on the business model and also handling of drugs, in the next stage they can expand their scope by way of employing qualified pharmacists and take on complete range of drugs in their shops. They can explore and set up the 'Jan Aushadhi' outlets in government hospitals and health centers with government assistance.

In this aspect the government agencies dealing with setting up of the central government scheme of 'Jan Aushadhi' or the state government level pharmacy initiative involving the SHGs should initially focus their efforts on female SHGs in urban setting, having better educated members to start with.

\section{References}

1. Schiller BR. The economics of poverty and discrimination. Upper Saddle River, NJ: Prentice Hall; 2001. p. 302.

2. Dror DM, Putten-Rademaker OV, Koren R. Cost of illness: Evidence from a study in five resource-poor locations in India. Indian Journal of Medical Research. 2008; 127:347-61. PMid: 18577789.

3. Oberholzer-Gee F, Khanna T, Knoop CI. Apollo-hospitalsfirst-world health care at emerging-market prices. Harvard Business School Case. 2007.

4. Bhargava A, Kalantri SP. The crisis in access to essential medicines in India: Key issues which call for action. Indian Journal of Medical Ethics. 2013; 10(2):70-5. Crossref

5. Desai C. Meyler's side effects of drugs: The international encyclopedia of adverse drug reactions and interactions. Indian Journal of Pharmacology. 2016 Mar; 48(2):224. PMCid: PMC4825447.

6. Brown DL. The high cost of poverty: Why the poor pay more. Washington Post. 2009 May.

7. Nair TS. Institutionalizing microfinance in India: An overview of strategic issues. Economic and Political Weekly. 2001 Jan; 36(4):399-404.

8. Raza WA, Van de Poel E, Panda P, Dror D, Bedi A. Healthcare seeking behavior among Self-help Group households in Rural Bihar and Uttar Pradesh, India. BMC Health Services Research. 2016 Jan; 16(1):1-13. PMid: 2672827, PMCid: PMC4698810. Crossref 
9. Joshi V, Panigrahi AK. Change for sustainable businesses; An Indian perspective with special reference to Indian pharmaceutical industry. Published in the Conference Proceedings of International Conference on Changes for Sustainable Business (NOVUS-2015); NIT Graduate School of Management; Nagpur. 2015 Feb. p. 1-15.

10. Nallani VR. Cost analysis study of oral anti-diabetic drugs available in Indian Govt generic (Jan Aushadhi, Jeevandhara). Drugs and Brand Drugs Market in Rural/ Urban Area of Guntur; Andhra Pradesh, India. Value in Health. 2015 Nov; 18(7):A717. PMid: 26534018. Crossref

11. Hussain S, Pharm M. Cost variation analysis of oral hypoglycaemic agents available in Indian market: An economic perspective. International Journal of Pharma Sciences and Research. 2015; 6(5):913-8.

12. Rao VN. Financial management practices for empowerment of women's Self-help Groups in micro finance - A study. Abhigyan. 2015 Apr; 33(1):12-23.

13. Brody C, De Hoop T, Vojtkova M, Warnock R, Dunbar M, Murthy P, Dworkin S. The effects of economic Self-help Group programs on women's empowerment: A systematic review. Campbell Systematic Reviews. 2015 Jan. p. 182.

14. Orlova LV, Sakhabieva GA, Vasyaycheva VA, Pronina NN. Impact of educational attainment on the development of female entrepreneurship in Kazakhstan. Indian Journal of Science and Technology. 2016 Mar; 9(11):1-8. 